\title{
Print Culture, Moral Panic, and the Administration of the Law : The London Crime Wave of 1744
}

The Herman Diederiks Prize Essay for 2012 / Lauréat du prix Herman Diederiks 2012

\section{Richard Ward}

\section{(2) OpenEdition}

\section{Journals}

Electronic version

URL: https://journals.openedition.org/chs/1317

DOI: $10.4000 /$ chs. 1317

ISSN: 1663-4837

\section{Publisher}

Librairie Droz

\section{Printed version}

Date of publication: 1 May 2012

Number of pages: 5-24

ISBN: 978-2-600-01594-3

ISSN: 1422-0857

\section{Electronic reference}

Richard Ward, "Print Culture, Moral Panic, and the Administration of the Law : The London Crime Wave of 1744", Crime, Histoire \& Sociétés / Crime, History \& Societies [Online], Vol. 16, n 1 | 2012, Online since 01 May 2015, connection on 23 March 2022. URL: http://journals.openedition.org/chs/1317 ; DOI: https://doi.org/10.4000/chs. 1317 


\title{
The Herman Diederiks Prize Essay for 2012 Lauréat du prix Herman Diederiks 2012
}

\author{
Print Culture, Moral Panic, and the Administration of the Law: \\ The London Crime Wave of 1744
}

\author{
Richard Ward ${ }^{1}$
}

\begin{abstract}
Au deuxième semestre de 1744, Londres fut saisie d'une panique morale relative à des vols avec violence commis dans les rues. Le présent article vise à montrer que de telles paniques liées à la sécurité ont existé depuis le milieu du XVIII siècle. Comme dans d'autres cas, la presse et l'opinion publique ont joué un rôle décisif en 1744. Différents genres de littérature criminelle insistaient sur le caractère spécialement menaçant de la criminalité de rue. En raison de l'alarme ainsi provoquée, le crime et la justice firent l'objet d'un vaste débat public dans la presse et l'administration judiciaire de la capitale connut différents changements. L'expansion de la culture de l'imprimé et les nouvelles occasions d'expression de l'opinion publique qui en résultèrent au XVIII ${ }^{e}$ siècle sont à la base de l'apparition de la forme moderne de la panique morale, phénomène qui continue d'avoir un impact significatif sur la justice pénale aujourd'hui encore.
\end{abstract}

In the second half of 1744, a moral panic about street robberies gripped London. The article argues that moral panics of the modern law and order variety are evident as early as the mid-eighteenth century. As with other historical panics, printed media and public opinion played a key role in driving the panic of 1744. Various genres of crime literature presented street robbery as an especially threatening problem. In the wake of this alarm, crime and justice came in for extensive public discussion in the press, and several changes were made to the administration of the law in the metropolis. The expansion of print culture and new opportunities for voicing public opinion in the eighteenth century provided the essential foundations for the genesis of the modern form of moral panic, a phenomenon which continues to have a significant impact upon criminal justice policy today.

\section{INTRODUCTION}

Tn the second half of 1744 a sudden and serious panic about violent street robberies gripped London. Countless reports of attacks committed by armed and brutal footpads filled the pages of metropolitan newspapers and the subject was covered in further detail by several other genres of print including periodicals, criminal biographies, the Ordinary's Accounts of malefactors executed at Tyburn, and the Old Bailey Proceedings - printed accounts of trials held at London's

1 His current research investigates what impact printed crime literature had upon criminal justice policy and perceptions of crime in eighteenth-century London. 
Central Criminal Court (hereafter Proceedings). In the wake of this alarm, several changes in the administration of the law were introduced across local and central government. Historians have largely by-passed the crime wave itself, concentrating instead upon what the events encompassed within it reveal of criminal organisation and thief-taking in the capital ${ }^{2}$. But it will here be argued that there is much value in studying the 1744 crime wave as a phenomenon in its own right. Firstly, because it demonstrates that the concept of moral panic provides a useful interpretive framework for understanding the mechanisms at work behind crime waves, events which often resulted in significant developments to the law and criminal justice. And secondly, because it provides an illuminating window onto the important and heretofore largely neglected - issue of the relationship between print culture, the public sphere, and the administration of the law. The long eighteenth century has been variously described as a 'golden age of writing about crime', a 'golden age of uncorrupted public opinion,' and the 'golden age of discretionary justice's. Much separate work has been undertaken on eighteenth-century crime literature, the transformation of the bourgeois public sphere, and the administration of the law, but we have little sense of how these forces interacted with one another. There is certainly much reason to suggest that the increasingly prominent and powerful forces of print culture and public opinion were intimately linked to, and could have a potentially significant impact upon, the administration of the law.

Crime, justice and the law formed a prevalent feature of eighteenth-century London's vibrant print culture. New forms of crime literature based upon the principle of periodical production which emerged in the late seventeenth and early eighteenth century and which expanded following the end of pre-publication censorship in 1695 - including newspapers, the Proceedings, and the Ordinary's Accounts - radically altered the transmission of information and offered novel perspectives on crime and justice ${ }^{4}$. Eighteenth-century Londoners could certainly learn about crime and justice from sources other than print, including direct experience as victims of crime or through attending the public forums of prison, trial, and punishment. Nevertheless, contemporary diaries and correspondence make it clear that perceptions were heavily influenced by crime literature. Some engaged critically with this material, but for the most part readers seem to have taken crime literature - particularly newspapers and the Proceedings - at face value, regularly coming to the conclusion that crime was a serious and threatening social problem ${ }^{5}$. Gertrude Savile, a well-bred gentlewoman living in mid-eighteenth-century London, for instance read a plethora of printed works, including several genres of crime literature, and expressed anxieties about the state of crime upon the basis of this information. In August 1728 she noted in her diary, "read the news and sent it to brother; abundance of street robberies again." In September 1744, when reports of robberies poured forth from the metropolitan press, she again wrote that "never were known so many and such bold roberys [sic] in the streets of late"

Beattie (2001, pp. 406-413); Linebaugh (1991, pp. 149-150); Paley (1989); Shore (2007, p. 59).

Shoemaker (2009, p. 18); Cowan (2001, p. 129); King (2000, p. 355).

Harris (1999, p. 13-26); Shoemaker (2010, p. 75).

5 For a more detailed discussion of the contemporary reception of crime literature, see Ward (2010, Ch. 2).

${ }^{6} \quad$ Saville (1997, pp. $133 \&$ 255). 
Moreover, the expansion of print culture, especially newspapers, in the eighteenth century helped constitute the bourgeois public sphere, providing a crucial medium through which contemporaries could voice their 'public opinion', an increasingly influential 'nominal' and 'real' force in discussions about crime and justice'. Disturbed by the problems of poverty, vagrancy, and crime wrought by London's rapid development in the late seventeenth and eighteenth centuries, and informed about these issues through the medium of print, middling men looked to air their concerns through the press and the institutions open to them. The press was used "as a vehicle to generate sympathetic public opinion, one of the most powerful means for individuals and interest groups to push the reactive state, and especially Parliament, to address an issue"8.

As David Lemmings proposes, it could be that "popular engagement with the administration of justice and the business of law making and governance assumed new cultural forms through middle-class habits of print culture consumption and the development of "polite' moral consensus" as promoted through the public sphere'. "The hitherto unknown conjunction of a broad-circulation press, the anxiety-driven middle-class public, and regularly parliamentary sessions" in the eighteenth century provided the "necessary ingredients for modern moral panics of the 'law and order' variety" 10 . The broad middling ranks of society who constituted the primary audience for printed crime literature were, as Peter King notes, the key decision makers in the criminal justice system, the "main group that made things happen", enjoying extensive discretionary powers across almost all stages of the judicial process ${ }^{11}$. Open forums of local government in London, the central role of the middling orders in the 'reactive' state, and the centrality of the metropolis in terms of national criminal justice policy moreover meant that middling Londoners could have a significant impact upon both the making of the criminal law and its administration.

All this suggests that we need to pay closer attention to the interaction between print culture, the public sphere, and the administration of the law in the eighteenth century. Moral panics provide a potentially fruitful opportunity for doing so. Recent studies have demonstrated that popular engagement with criminal justice "frequently took the form of moral panics that generated demands for enforced social discipline"12. "Media-driven panics associated with moral threats which produced law reactions" can indeed be identified in the eighteenth century, stretching from violent street crime to sexual assault and gambling ${ }^{13}$. Defining moral panic as "a discrete event or cycle of events with a beginning and an end, which follows a process and has a product", Peter King has provided a suggestive comparison of four separate historical moral panics about violent street crime: Colchester in 1765, London in 1862, Britain in 1972, and New York in 1976. He identifies a six-stage pattern common to all ${ }^{14}$, that might be briefly summarised as follows : firstly, an initial

For notions of the 'nominal' and 'real' public sphere, see Zaret (2000).

8 Davison et al. (1992, p. xiii).

9 Lemmings (2009b, p. 5); King (2000, p. 359).

10 Lemmings, (2009b, p. 2).

11 King (2000, p. 355).

12 Lemmings (2009a, p. 264).

13 Lemmings (2009b, p. 12).

14 King (2003). King's model is built upon earlier influential studies including Cohen (1972) and Hall (1978). 
act (or acts) provokes media attention on a particular theme; secondly, the media then exaggerate the threat posed by the type of offence under attention; thirdly, this leads to an increase in crime reported to the authorities; fourthly, the extent of crime is overestimated by the media and the authorities; fifthly, new and heavier control and punishment measures are introduced; and finally, after a couple of months or so, the panic dies away ${ }^{15}$. It will be shown that the London crime wave of 1744 closely fits this model, particularly in terms of timing, duration, and lifecycle. When viewed through the lens of moral panic, flashpoints such as the London crime wave of 1744 can help us to better understand the eighteenth-century nexus between print culture, the public sphere, and the administration of the law.

\section{ORIGINS OF THE PANIC}

Concerns about an apparent wave of violent street robberies seemingly besetting the metropolis first began to emerge in the press in July 1744, with the Daily Advertiser complaining that thieves appeared "now as daring and barbarous as those of Paris"16. In a report printed in many other metropolitan newspapers, the London Evening Post at the beginning of August further contended that "the many instances of robberies lately committed in and about London, and the barbarity and insolence of the fellows that commit them, who are secure in their number, calls for the utmost care and vigilance of the magistracy, as well as the concurrence and assistance of all honest people to put an immediate stop to this growing evil" ${ }^{17}$. Historians have attributed the apparent spate of - and concomitant moral panic about - robberies on London's streets in the second half of 1744 to the activities of a gang of offenders operating out of a base in Black Boy Alley, off Chick Lane, in the ward of Farringdon Without, "a notoriously dangerous part of the City" ${ }^{18}$. Moral panics cannot of course be manufactured without at least some 'real' crime, and it is certainly likely that individuals associated with the Black Boy Alley Gang had committed numerous offences in the capital at this time, with reports of such crimes and the alarm it generated amongst victims to some extent filtering through to the press ${ }^{19}$.

However, because we cannot recover the level of 'real' crime committed by the Black Boy Alley Gang it is impossible to measure the impact its activities had upon levels of crime reporting. Moreover, it is becoming increasingly clear that eighteenthcentury crime news was constructed according to factors other than the level of 'real' - or even prosecuted - crime alone, such as editorial decision-making linked to the newsworthiness of different types of crime, the availability of alternative sources of news, and the particular social personality of individual publications ${ }^{20}$.

$\overline{15}$ King (2003, p. 70).

16 Daily Advertiser, 10 July 1744. All the newspapers cited in this article have been consulted through the $17^{\text {th }}-18^{\text {th }}$ Century Burney Collection of Newspapers website [http ://find.galegroup.com], accessed 29 November 2010).

17 London Evening Post, 2 August 1744.

18 Beattie (2001, p. 406).

19 Although, as Ruth Paley rightly notes, the charges on which the gang were variously brought to justice seem somewhat suspicious and constructed for the occasion. See Paley (1989, p. 325).

20 King (2009); Snell (2007); Ward, (2010, Ch. 6). 
No doubt there was almost always a pool of crime reports which editors could draw upon, and their choice of what to include was influenced by circumstances other than the changing levels of reports sent in. Indeed, there is evidence to suggest that metropolitan newspaper editors were becoming more interested in the issue of crime in mid-1744 because of a lack of alternative news - as well as an apparent increase in offending.

Foreign news constituted the primary staple of the eighteenth-century press, and since the War of Jenkins' Ear and the subsequent War of the Austrian Succession in 1739, editors of London newspapers had been blessed with bountiful material. By 7 September 1744, however, newspapers such as the Daily Post were complaining about the current 'dearth' of news, especially that from overseas ${ }^{21}$. In the face of this apparent dearth of foreign news, it is perhaps the case that editors looked to crime and justice, another staple of the press, for replacement copy. Tellingly reflecting this shift in the newspapers' attention from foreign to domestic crime news, the Daily Post on 25 September 1744 commented that "the clamours of villainy abroad are silenced by the state of wickedness at home"22. Indeed, such was the desire for news of street robberies that it appears some editors printed false and unjustified reports. No doubt with the ulterior motive of denigrating the competition, the Daily Post at the end of September alleged that "the robbery mention'd in some of the papers yesterday, of some fellows coming in a coach to Mr Pelah's, and demanding his money, is without foundation; there being not the least reason for such a report"23.

Increased press interest in the subject of street robberies in mid-1744 therefore likely resulted from both growing criminality and an editorial need for copy when faced with a dearth of foreign news. Complaints regularly appeared in metropolitan papers in July and August of the insolence and barbarity of street robbers. Only worse could be expected to come: if due care was not taken, the London Evening Post warned at the beginning of August, then the current swarm of robbers infesting London's streets would "speedily raise contributions from the inhabitants of this City, as was done some time since by a gang of desperate fellows in Dublin"24. Autumn and winter's ominous approach - and the dangers of darkened streets that this entailed - also brought anticipations of a growing crime problem. Reports of gentlemen assaulted and robbed in the streets by "a gang of desperadoes arm'd with cutlasses" were "only earnests of what may happen before Christmas" 25 . Unless the recent spate of street robberies be "speedily and totally suppress'd", noted the Ordinary's Account, "it will really become difficult to get an honest livelihood; because in the winter half year, the mornings and evenings will be in a manner useless, and all people forced to do their business (without doors at least) in the middle of the day"26.

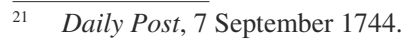

22 Daily Post, 25 September 1744.

23 Daily Post, 29 September 1744.

24 London Evening Post, 2 August 1744.

25 Penny London Post, 25 September 1744.

26 Old Bailey Proceedings Online (hereafter OBP), (http ://www.oldbaileyonline.org, accessed 29 November 2010), Ordinary's Account, October 1744 (OA17441005). Ordinary's Accounts included on the $O B P$ website are cited with the date on which the edition was published and the project's document reference number. Editions of the Proceedings included on the site have been cited with the defendant's name, the month and year of the sessions, and the project's trial reference number. 
Throughout July to mid-September 1744, London newspapers thus showed a growing interest in the subject of street robbery, and expressed some initial and serious, but rather general, concerns about its scale and nature. These were based upon a few individual and largely unspecified reports of the offence, anticipating a worsening crime problem to come. Events of late September to December 1744 subsequently (and to contemporaries, regrettably) confirmed such anticipations and gave sharper definition to the initial concerns voiced in the press, exaggerating the threat posed by street robbery through the creation of negative and fearful stereotypes. These events included the prosecution of a number of notorious street robbers linked to the Black Boy Alley Gang and reports of attacks committed against peace officers by gangs of insolent offenders, all covered in extensive detail in London newspapers, the Proceedings, and the Ordinary's Accounts ${ }^{27}$. Whilst media attention was increasing before late September, it was from that time that the printed coverage of the crime wave really took off and helped create a full-scale moral panic about street robbery.

\section{PRINTED COVERAGE OF THE CRIME WAVE}

A systematic quantitative analysis of levels of crime reporting in the metropolitan press has not been undertaken here. But even upon a cursory view it is clear that there was a large increase in the news-hole devoted to the subject of street robbery in many London newspapers in the final third of 1744. In September, for example, crime reports branched out from the traditional confines of the 'Robbed' section of the weekly Country Journal or the Craftsman and into its main 'London News' segment. By October 1744 the London Evening Post was regularly devoting a whole column solely to reports of street robberies. Several publications - the Daily Advertiser in particular - also began to print extended commentaries on the crime problem ${ }^{28}$. Likewise, the amount of print dedicated to street robbery increased substantially in the pages of the Ordinary's Accounts and the Proceedings. Together this extended printed coverage presented street robberies as unprecedented in number, committed by multiple gangs of barbarous and insolent offenders acting in direct opposition to the peace-keeping authorities, in all public spaces and at all times of the day. As the Daily Advertiser summarised in mid-December 1744 - just as the panic began to abate - the grievance that had preoccupied the press so ubiquitously over the past few months was the "street robberies, which are committed by force of arms and dint of numbers, as well by day as by night, in the most notorious manner, equally in opposition to law and government, as to power both civil and military; a truth too well known to require any further evidence than the bare mentioning of it" 29 .

Crime literature certainly portrayed robbery as unprecedented in scale and nature at this time. Newspapers regularly referred to the "daily" and "nightly" scenes of villainy, the "continual" robberies and "swarms of street robbers" which "infested"

\footnotetext{
27 For the printed reports of the trials of members of the Black Boy Alley Gang see $O B P, \mathrm{t} 17440912$ 48; t17440912-49; t17440912-50; t17440912-51; t17441017-6; t17441017-7; t17441017-22; t17441017-28; t17441205-24; t17441205-34; t17441205-37; t17441205-61.

28 See for instance London Evening Post, 25 September 1744.

29 Daily Advertiser, 13 December 1744.
} 
the metropolis. Reflections on prosecution rates also confirmed the unprecedented scale of criminality, the Penny London Post asserting of the December gaol delivery sessions at the Old Bailey that, "there never was known, at one sessions, so many prisoners to be try'd for capital offences" ${ }^{\prime 3}$. This was indeed correct: the total of twenty-two trials at the Old Bailey for violent theft in December 1744 was the greatest thus far in the eighteenth century, and anywhere near such a figure at one single session had not been witnessed since that of September $1732^{31}$. "Now the scene is changed" asserted John Applebee in the Ordinary's Account of October 1744, for robberies and murders were seemingly "as frequent [in London] as anywhere" in Europe ${ }^{32}$. Two months later he bemoaned the currently unparalleled scenes of villainy, and "the daily numerous instances of unprecedented barbarity" 33 . Coverage of the prosecution of notorious offenders linked to the Black Boy Alley Gang furthermore promoted an image of street robbers as habitual offenders. A report of the trial of Luke Ryley and John Mackavoy for street robbery printed in the Proceedings in September mentioned the "fifteen or sixteen" robberies they had committed in the past six weeks, and listed some thirteen additional bills of indictment upon which they could have been charged (London newspapers in fact claimed the number was twenty-eight) ${ }^{34}$. Never before had such levels of violent theft been witnessed at the Old Bailey and we should certainly not discount the anxiety that the sheer numbers aroused. But it is also likely that the way in which this increase in prosecution levels was covered by print helped to reinforce such fears.

These recent 'daily' instances of street robbery were attributed in crime literature not just to the activities of the Black Boy Alley Gang, but more broadly to the existence of numerous gangs and 'swarms' of offenders, extending the panic to a wider concern about violent crime and criminal organisation in general. Frequent street robberies were "not occasioned by one or two gangs of harden'd villains" it was proposed in the Ordinary's Account, but were rather "owing to such numbers betaking themselves to these wicked practices" ${ }^{35}$. The press moreover linked together different - and perhaps in actual fact unconnected - offences under the auspices of gangs supposedly terrorising particular neighbourhoods ${ }^{36}$. Specific reference had been made to the Black Boy Alley Gang as early as October 1744 in the pages of the Proceedings: "tis a bad place" one witness claimed in a trial report printed in the Proceedings, "the very sanction of Black Boy Alley will hang a hundred [accused offenders] with very little evidence, no matter who swears" ${ }^{37}$. Yet it was really only from December that the gang was retrospectively identified in crime literature as to blame for the crime wave and established as a trope of crime reporting. Applebee

30 Penny London Post or Morning Advertiser, 26 November 1744.

$31 O B P$, 'Statistics' search : counting only by the offence category of violent theft, by sessions.

32 OBP, Ordinary's Account, October 1744 (OA17441005). Although James Guthrie was officially the Ordinary of Newgate at this time, since 1735 he had agreed to cede the writing of the Ordinary's Account to the printer Applebee in exchange for a fee. See McKenzie (2007).

33 OBP, Ordinary's Account, December 1744 (OA17441224).

34 OBP, trial of Luke Ryley and John Mackavoy, September 1744 (t17440912-50); Country Journal or the Craftsman, 22 September 1744.

35 OBP, Ordinary's Account, October 1744 (OA17441005).

36 See for example London Evening Post, 11 September 1744.

37 OBP, trial of Ann Collier, December 1744 (t17441205-61). 
made his first specific reference to the Black Boy Alley Crew in the pages of the Ordinary's Account as late as the final week of 1744. Here he named nine men, who had been sentenced to death at the sessions of the Old Bailey a few weeks previously, as within its ranks, and retrospectively included three women who had been executed in November ${ }^{38}$. And even as the Black Boy Alley Gang was increasingly associated with the recent wave of street robberies and as the group itself became a prominent theme of crime reporting in December 1744, comments continued to appear in print about the multitude of different gangs terrorising London. The Ordinary's Account at the end of December, for instance, made reference to "diverse gangs of thieves and street-robbers" 39 .

According to comments made in print, such gangs were populated by offenders of unmatched violence and insolence. London newspapers referred to the many "barbarities" and "cruelties" committed by street robbers ${ }^{40}$. Several papers in September 1744 printed a report of how a mother carrying her young child was set upon by "four ruffians", one of whom struck at the woman, "but the blow miss'd her, and fell on the head of the infant with such force, that it beat out its brains, and it died on the spot" ${ }^{\text {"41. }}$ The Daily Advertiser noted that few people dared to assist peace officers in taking the "numerous gangs" committing "continual robberies" because of "being in danger of their lives" ${ }^{2}$. Trial reports printed in the Proceedings certainly highlighted the dangers open to individuals in attempting to apprehend street robbers. One victim of highway robbery was reportedly set upon by four or five "lusty fellows" who "damned his eyes to let them go", or face being cut "as small as sausages" 43 . The apprehending of "such a profligate set of audacious bloodthirsty desperate, and harden'd villains", the Ordinary confirmed in his Account, "is an undertaking worthy of the greatest encouragement, and more especially, when such an undertaking is attended with the greatest danger and hazard" $" 4$.

Reports regularly noted that offences were carried out with impunity in "contempt and defiance of the laws" 45 . The General Advertiser told of a "number of ruffians, who insolently and audaciously beat and insulted several persons in the street at their own doors... and so early in the night that people were continually passing to and fro" ${ }^{46}$. Robbers had the impudence to rob during the daytime and in sight of the watch, confident that if taken, accomplices would rescue them. "The insolence of our thieves is come to such a height, that small bye-streets are not safe in the day" complained the Ordinary's Account ${ }^{47}$. Reports of criminals rescued "in triumph" from the clutches of the peace-keeping forces and attacks on officers became a prominent theme of crime literature in late 1744. In the final week of September many reports

OBP, Ordinary's Account, December 1744 (OA17441224).

OBP, Ordinary's Account, December 1744 (OA17441224).

Daily Advertiser, 12 \& 24 October 1744.

Country Journal or the Craftsman, 22 September 1744.

Daily Advertiser, 24 September 1744.

$O B P$, trial of John Peirson and Joseph Fitzwalter, September 1744 (17440912-51).

OBP, Ordinary's Account, December 1744 (OA17441224).

Daily Advertiser, 25 October 1744.

General Advertiser, 24 September 1744.

OBP, Ordinary's Account, October 1744 (OA17441005). 
appeared in London newspapers of officials such as Alexander Forfar (headborough for St James, Clerkenwell) and Edward Jones (City Marshal) in addition to their constables and other peace officers coming under attack in endeavouring to arrest street robbers ${ }^{48}$. According to the Gentleman's Magazine, Jones was attacked by twelve villains carrying cutlasses and pistols, crying out their intention to "defy all power" and thus the details of the case gained even greater printed coverage through trial reports published in the Proceeding $s^{50}$. By creating rescue as a coherent 'theme' of reportage, reports served to reinforce the validity of the theme. As one self-reflecting report in the Daily Advertiser of July 1744 commented after describing how two robbers had been rescued from custody by the assistance of their gang, "the civil power of committing felons is quite obstructed, and instead of paragraphs reciting offenders, crimes and their commitments, nothing but rescues now fill the papers"51.

\section{PUBLIC DISCUSSION OF, AND RESPONSES TO, THE CRIME WAVE}

King's pattern of moral panic states that after the media turns its attention to a particular theme and exaggerates the threat posed by an offence, this results in an increase of such crime reported, and the extent of crime is overestimated by the media, the public, and the authorities ${ }^{52}$. In the second half of 1744 crime literature certainly presented the recent wave of street robberies in London as a serious and threatening social problem through the use of negative and fearful stereotypes. How exaggerated was this representation, and did it lead to an overestimation of the extent of street robbery? As acknowledged above, we cannot compile past 'real' crime levels. It is therefore impossible to demonstrate whether - and if so, to what extent - the media overestimated the prevalence of street robberies and whether the media coverage resulted in an increase in the number of offences brought to trial, because we have little historical evidence of the realities of crime in this period. Much more can however be said in relation to the fifth stage of moral panic, namely the solutions to the crime wave promoted in print and the methods actually adopted by the authorities. As in other historical moral panics, new heavier control and punishment measures were put forward in the press and - to a lesser extent introduced by the authorities in the final months of 1744 in an attempt to suppress the perceived crime wave gripping London ${ }^{53}$.

In stark contrast to other London newspapers - which reproduced few readers' commentaries, if any at all - the printer of the Daily Advertiser on 1 October 1744 assured readers that any letters sent to the paper proposing solutions to the current problem of street robberies would be "publish'd with thanks, and the utmost

\footnotetext{
48 London Evening Post, 25 September 1744.

49 Gentleman's Magazine, 14 (1744), p. 505.

50 OBP, trial of Thomas Wells, Theophilus Watson, Joshua Barnes, Thomas Kirby, and Ann Duck, October 1744 (t17441017-6), (t17441017-7).

51 Daily Advertiser, 13 July 1744.

$52 \quad$ King (2003, p. 55).

53 Ibid.
} 
impartiality, at no expence to the author." A total of thirty letters duly appeared in the paper over the following two months, printed on a daily basis and as leading articles. These commentaries offer fascinating insights not only into contemporary views about responses to crime, but also the nature of the public sphere and its intimate links to the administration of the law. Since at least the beginning of the eighteenth century, newspapers had provided an innovative vehicle for expressing views about crime and justice, one far more accessible and immediate than that offered by pamphlets of social commentary. How was this opportunity for expression articulated in the press, who seized upon it, with what justification, and with what outcomes in mind? These penetrating questions can only be touched upon here.

Huge stress was placed by the printer of the Daily Advertiser on the open and impartial nature of the opportunity open to readers, assuring them that no schemes sent in would be withheld "through partiality, or out of disregard to the performances, but either because the same subject had been treated in the same manner by other writers, or that they were too long to be contained within the compass of this paper" ${ }^{\prime \prime}$. Schemes would instead be published out of a "sincere desire to contribute to the welfare of the community" 55 . Authors of schemes of course agreed wholeheartedly with the endeavour, praising the publisher's "truly noble proposal" ${ }^{56}$. Such contributors for the most part chose to remain anonymous. No conclusions can therefore be given as to the social status or background of those who took advantage of this opportunity to voice their opinions within the public sphere, and it cannot be said without question that the letters were not manufactured by the Daily Advertiser's editor. However, the internal evidence of language and style highly suggests that the letters were genuinely individual and original contributions. Anticipating a desire for anonymity, the editor requested that contributors nonetheless mark their schemes with some "letter or token" in order that readers might distinguish between commentators ${ }^{57}$. The range of pseudonyms adopted by correspondents does provide some indication of the publicly-spirited and positive intentions that lay behind contributions: 'Bono Publico', 'Well-Meaner', and 'Amicus Reipuplicae' [sic] to name just a few.

Both the printer of the Daily Advertiser and contributors to the paper constantly justified their commentaries upon the basis of the public good. As both a nominal force to which the contributors to the press and the authorities made reference in order to justify their respective interventions on the issue of crime and justice, as well as a very real force which the powers-that-be had to accommodate themselves to, the notion of the 'public' also played a crucial role in the moral panic about street robbery in 1744. Indeed, the notion of the 'public' provided the crucial foundation for the whole episode. Schemes would be printed "for the information of the publick", the Daily Advertiser noted in its initial invitation to readers ${ }^{58}$. Likewise, correspondents humbly laid their schemes before the 'public', offered purely with a "view to promote the publick service", and acknowledging that proposals were ultimately dependent upon the public's approval ${ }^{59}$. Signing himself 'BF', one correspondent submitted

\footnotetext{
54 Daily Advertiser, 13 December 1744.

55 Daily Advertiser, 1 \& 12 October 1744.

56 Daily Advertiser, 18 October 1744.

57 Daily Advertiser, 1 October 1744.

58 Daily Advertiser, 27 September 1744.

59 Daily Advertiser, 1 October 1744.
} 
his scheme "to the remark, censure, or amendment of the publick" ${ }^{\circ 0}$. In attempting to justify his/her proposal for the physical maiming of convicted offenders before transportation - in order that offenders forever carry their "marks of villainy" - one contributor to the press appealed to the apparent support of "the sense of the publick upon this head" 61 . Others in a rather modest, apologetic, and deferential manner hoped that their proposals would be considered by "better heads" or "abler pens" Many contributors were also in expectation that by voicing their schemes within the public sphere they might come to the attention of criminal justice officials or the legislature ${ }^{63}$. "We hope enough has been said to furnish those whom it does most concern", commented the Daily Advertiser's publisher, "with proper materials to put some check to the progress of the evil" of frequent street robberies ${ }^{64}$.

Why did the Daily Advertiser's publisher, Matthew Jenour, open up the pages of the paper to correspondents? Again, with little evidence available this question cannot be fully answered, but a few factors can be explored. It is unlikely that Jenour inserted the letters as part of a broader political agenda. Although certainly Whig in its political stance and highly supportive of the Walpole administration, nevertheless the Daily Advertiser was emphatically not dictated by political influence, as demonstrated by its refusal in 1744 to print a letter written by Lord Chancellor Hardwicke calling for restraints on the printed reporting of parliamentary news ${ }^{65}$. The actual letters printed in the Daily Advertiser in the autumn of 1744 do not demonstrate an avowedly pro- or anti-ministerial stance. Criticisms were certainly lodged against the authorities, although voiced apologetically. The crime wave was in no way used by the main opposition paper of the day, the London Evening Post, to beat the administration with. As with the metropolitan press of the later eighteenthcentury, it does not seem that the coverage of crime in mid-century newspapers was largely influenced by political affiliation ${ }^{66}$.

Nor does it appear likely that the decision to call for contributions from correspondents was a result of financial considerations. Stamped daily newspapers such as the Daily Advertiser had faced strong competition from cheap, unstamped and therefore illegal - publications in the 1730s and early 1740s, but a government crackdown against these illegitimate titles in 1743 had largely dealt with the threat. Evidence of print-runs - although admittedly tentative - for the London Daily Post in fact suggests that demand for stamped dailies was increasing between 1743 and $1746^{67}$. The Daily Advertiser was the most successful daily paper of its day, likely selling at a rate of over 2,500 copies per issue ${ }^{68}$. Within the context of long-term finances, there was little reason for the Daily Advertiser's printer to change editorial tact, for he was already onto a winning formula.

\footnotetext{
60 Daily Advertiser, 26 October 1744.

61 Ibidem.

62 Daily Advertiser, 1 November 1744.

63 Daily Advertiser, 26 October 1744.

64 Daily Advertiser, 14 December 1744.

65 Black (1987, p. 170).

66 Devereaux (2007, p. 9).

67 Harris $(1987$, p. 57).

68 Harris (1987, p. 190).
} 
The more likely explanation for the Daily Advertiser's call to correspondents in 1744 lies, as already mentioned, in the general desire for content at this time. Well known for its coverage of foreign news, the 'dearth' of information on this subject in mid-1744 may have the DailyAdvertiser's editor harder than others. July to September moreover tended to be the slackest months in terms of sales and advertisements for London dailies ${ }^{69}$. Matthew Jenour was perhaps therefore in desperate need of content and a 'hook' on the currently prevalent theme of crime in mid-1744. Letters of correspondence offered a cheap, quick, and relatively easy fix to this conundrum.

Of course, without concrete evidence this can only be speculation. It does suggest that the events of later 1744 to some extent at least reveal more about the peculiarities of one paper than a more general interaction between criminal justice, print culture, and the public sphere. But it can be countered that the language of the letters printed in the Daily Advertiser indicate that there was an on-going public debate about crime and justice, and that readers were very familiar with the opportunity offered by the press to voice opinions to a large audience. Moreover, there are other examples of newspaper editors printing correspondence on the issue of crime and justice. During the post-1747 London crime wave for instance many titles published letters from contributors on the crime problem then besieging the metropolis. What is clear is that more work needs to be done on how crime news was constructed in the eighteenthcentury press and on other crime waves in order to understand how frequently the pages of newspapers were opened up to correspondents on the issue of crime and justice. This will provide a better understanding of what events such as that of 1744 actually reveal, whether it be the peculiarities of newspaper production, or a more general interaction between print culture, the public sphere, crime, and justice.

What kinds of solutions to the crime wave were printed in the Daily Advertiser and which methods were adopted in actual practice by the authorities? Schemes sent in by readers exposed a number of eighteenth-century debates about criminal justice policy, including the balance between public spirit and private incentive in policing, the legality and constitutionality of hard labour as a judicial punishment, and how the criminal law might be made more effective in deterring potential offenders. The 1744 crime wave generated extensive discussion of the justice system, with wideranging and often radical proposals aired in the public sphere, reflecting the scale of contemporary alarm. Proposals such as the extension of summary justice to include capital felonies or the abandonment of the royal prerogative of pardon challenged fundamental aspects of the criminal justice system, yet were evidently seriously considered by correspondents and deemed worthy of publication by the Daily Advertiser's printer. Although there was certainly a degree of similitude between the methods advocated in the public sphere and those put into practice at local and central government level, nevertheless the authorities' efforts were nowhere near as extensive or as radical as contributors to the Daily Advertiser hoped for.

Both the authorities and the contributors to the Daily Advertiser certainly agreed on the nature and causes of the crime wave. Commentators in the press regularly reiterated in similar terms the City aldermen and Lord Mayor's complaint at the beginning of October 1744 that the crime wave was due to the "diverse confederacies of great numbers of evil-disposed persons, armed with bludgeons, pistols, cutlasses,

$\overline{69} \quad$ Harris (1987, p. 60). 
and other dangerous weapons [that] infest not only the private lanes and passages, but likewise the publick streets and places of usual concourse, and commit most daring outrages..." 70 . They also concurred that the 'root' causes of the crime problem lay in the opportunities for vice, idleness, and immorality offered by the metropolis. Contributors to the Daily Advertiser deemed "excessive drinking of spirituous liquors... among the lower sort of people" the principal cause of violent thefts, for it corrupted the morals of the inferior ranks, led them into "wicked courses", made them averse to work, and rendered them "fit for any desperate cruel action" "11. Lewd women were understood to act out "the highest indecencies of debauchery and theft with impunity", necessitating that all nightwalkers should be apprehended and confined to hard labour in houses of correction. And "public gaming houses" were declared to "bring persons even of affluent fortunes to want, and then put them upon wicked and desperate measures to supply their necessities and extravagance" ${ }^{\text {"72. }}$. Many readers thus proposed greater social regulation and surveillance of places of public diversion in order to curb moral depravity. The pseudonymous 'Amicus Reipuplicae' for instance called for the identification of all "bad houses", their suppression by troops of foot guards, and rewards to be paid to all those apprehending frequenters of such places ${ }^{73}$. In a 'representation against street robbers and other disorderly persons' sent to the Duke of Newcastle in October 1744, the Middlesex justices likewise proposed suppressing the gaming houses which allegedly turned many to want and a life of crime, and suggested curtailing "the excessive use of spirituous liquors" which apparently emboldened offenders to "those cruelties which are now exercised on the persons robbed"74.

But more so than the apparent root causes of crime, contributors to the press as well as the authorities paid attention to the limits of the criminal justice system as an effective response to the crime wave. Correspondents to the Daily Advertiser regularly called for reform of the night watch and improvements to street lighting as a greater prevention to street robbery ${ }^{75}$. Metropolitan authorities did not instigate the kind of legislative reform of the night watch as some correspondents called for at this time, at parish or indeed any other level ${ }^{76}$. The authorities did however make at least some, more informal, efforts to encourage the prevention of crime as well as the detection and prosecution of offenders. In the second half of 1744, many reports appeared in the pages of London newspapers telling of local inhabitants raising subscriptions in order to fund extra patrols "for securing and apprehending the street robbers" $"$. The justices of Middlesex in October 1744 likewise agreed to pay a sum

70 Repertories of the Court of Aldermen, London Metropolitan Archives, COL/CA/01/01/148, p. 470476. See for example the Daily Advertiser, 13 December 1744.

71 London Gazette, 29 September 1744; Daily Advertiser, 7 November 1744.

72 Daily Advertiser, 27 October 1744, 13 December 1744; Universal Spectator and Weekly Journal, 8 September 1744.

73 Daily Advertiser, 25 October 1744.

74 London Lives 1690 to 1800 (hereafter London Lives) [http://www.londonlives.org], accessed 29 November 2010) Middlesex Sessions, General Orders of the Court, 19 October 1744, (LMSMGO5566020097). I have here followed the project directors' citation guide. Manuscripts are cited with the document title, the date of the material, and the document reference number.

75 Daily Advertiser, 19 October 1744, 24 October 1744, 2 November 1744.

76 Reynolds (1998, p. 28).

77 See for example London Evening Post, 20 October 1744. 
of six shillings to a party of the King's soldiers for assisting peace officers "in the apprehending and securing street robbers and gamblers"78. Indeed, as J.M. Beattie has shown in his detailed analysis of the City authorities' responses to the perceived crime wave, the aldermen and Lord Mayor regularly discussed the violent street crime throughout September and October $1744^{79}$. This perhaps came as a reaction to the demands placed on metropolitan magistrates by central government, which for its own part did not produce any legislative reforms to policing at this time. Lord Carteret had previously notified the magistrates of Westminster and Middlesex at the end of September 1744 of the King's great concern about "the frequent robberys [sic] and disorders of late committed", instructing them to organise privy searches in order to uncover the street robbers' places of resort, to hold frequent petty sessions, and to draw up reports of "the zeal and diligence" of magistrates and peace officers ${ }^{80}$. Upon reading Carteret's letter the Westminster justices made the rather perfunctory response of ordering the constables to "take all persons that go about the streets with pistols, cutlasses, bludgeons, and other offensive weapons" and carry such persons before the justices ${ }^{81}$. In April 1745 the Duke of Newcastle again called upon the Westminster justices to provide an account "of all their actions in apprehending robbers and vagrants" $" 82$.

At all levels of government efforts were made to increase the financial incentives behind the detection and prosecution of street robbers. Believing the streets to be "of late greatly infested by a notorious gang of street robbers and pickpockets", the vestry of St Clement Danes on 18 September 1744 agreed to advertise a reward of ten guineas to be paid to anyone successfully prosecuting a street robbery committed in the parish ${ }^{83}$. The aldermen and Lord Mayor of the City also offered a reward of $£ 5$ purely for the arrest of a suspect and - in order to facilitate costly prosecutions - a further $£ 5$ to be paid upon a conviction, a practice which three Middlesex justices writing to the Duke of Newcastle in October 1744 recommended extending to the metropolis more widely ${ }^{84}$. They also suggested that the royal proclamation offering $£ 100$ for the conviction of anyone committing robbery or attempting to rob with an offensive weapon should be reduced to $£ 40$, with payments handed out in open court, thereby making the reward system both speedier and more transparent ${ }^{85}$. Rejecting this suggestion, the central executive at the beginning of November instead decided to simply reissue the proclamation, a policy for the most part intended to stop openended rewards rather than to suppress street robberies ${ }^{86}$. Contributors to the press certainly agreed with the centrality of rewards to the justice system. Complaints were not so much levelled against the existence of the rewards themselves, but rather against delays and irregularities in the payment of rewards. Printed schemes thus

\footnotetext{
78 London Lives, Middlesex Sessions, General Orders of the Court, October 1744(LMSMGO556020097).

79 Beattie (2001, p. 407).

80 State Papers Domestic, The National Archives, SP 36/64/310-311.

81 London Lives, Westminster Sessions, Justices' Petty Sessions, September 1744 (LMWJPS654340019).

82 State Papers Domestic, The National Archives, SP 36/65/217.

83 London Lives, StClement Danes, Minutes of Parish Vestries, September 1744(WCCDMV362070280).

84 Repertories of the Court of Aldermen, London Metropolitan Archives, COL/CA/01/01/148, pp. 411, $419-420,425, \& 446-449$.

85 State Papers Domestic, The National Archives, SP 36/64/339.

86 Beattie (2001, p. 408).
} 
called for the immediate payment of rewards after conviction, and for rewards to be paid upon the committal of any robber - whether judged guilty or not by the courts - in order to defray the immediate costs of prosecution. Few seemed to believe that massive rewards were an incitement to false arrests or prosecutions ${ }^{87}$.

Solutions to the crime problem also centred upon the penal system. Contributors to the press expressed concerns that the "too frequent" instances of royal pardons granted to offenders convicted of capital crimes such as street robbery consequently reduced the terror of death and thereby undermined the deterrent objective of capital punishment. Some therefore called for a restriction in the frequency of pardons, others - and more radically - for the total abandonment of the practice ${ }^{88}$. In an address to the King - published in numerous London newspapers - the City aldermen and Lord Mayor also asked for fewer royal pardons for convicted offenders, hoping that "a speedy, rigorous and exemplary execution of the laws" might "conduce greatly to the suppressing these enormities, by striking terror into the wicked, and preventing others from entering into such evil courses" $"$. The King and the cabinet seem to have agreed with this request, severely reducing the number of pardons granted to convicted robbers in the final few months of 1744. Commentators in the press also suggested a number of other changes to penal practice. The pseudonymous 'Publicus' for instance asserted that "the increase of [street robbers] is in a great measure owing to the punishments inflicted not answering the end intended", and that as "idleness is the chief reason why they take to this course of life", so if upon conviction they would be "put immediately to hard labour during life", it would prove more effectual than hanging or transportation. He also suggested that convicted murderers should be executed immediately, "without allowing them time to prepare for death, for as they gave no respite to those they murder'd, so neither should they be allow'd any." Lengthy periods of time spent in prison for those awaiting trial or execution were believed to corrupt the morals of minor offenders even further, and also allowed those sentenced to death to spend their time soliciting for a royal pardon rather than taking care for the state of their soul ${ }^{90}$. Another correspondent to the London Magazine in late 1744 declared that "all other nations... adapt punishments to crimes", and thus suggested that if heinous offenders were fed to the lions and tigers kept in the Tower of London, it might enhance the deterrent capacity of capital punishment ${ }^{91}$. Nevertheless, none of these suggestions were adopted in actual practice, with no new pieces of legislation enacted. The authorities apparently considered a sudden increase in the number of offenders hanged to have been a sufficient penal response to the crime wave.

87 Daily Advertiser, 9 October 1744, 25 October 1744, 12 November 1744; General Advertiser, 4 October 1744; London Evening Post, 22 September 1744.

${ }_{88}$ Daily Advertiser, 19 October 1744; London Evening Post, 13 October 1744.

89 Repertories of the Court of Aldermen, London Metropolitan Archives, COL/CA/01/01/148, pp. 470476.

90 Daily Advertiser, 19 October 1744.

91 Cited in McGowen (2004, p. 223). 


\section{DECLINE OF THE PANIC}

Many of the responses to the moral panic about street robberies undertaken by the authorities in later 1744 therefore simply involved voicing complaints about the criminal justice system or the current efforts to tackle the perceived root causes of crime, and calling upon others to improve the situation. For instance, the metropolitan magistrates made requests to the central government and the King to introduce legislation relating to the reward system and street lighting. By contrast, the secretaries of state called upon justices to act with greater assiduity and diligence. Although the authorities certainly introduced some practical measures to combat the crime wave, these were modest compared to the schemes printed in the press and aired in the public sphere. But in spite of the modest nature of the responses, it is nonetheless the case that the printed coverage of, and moral panic about, the crime wave quickly died away from the middle of December 1744. After this time the scale of newspaper crime reporting declined dramatically, and the qualitative nature of the reportage became less anxious and sensationalist in tone. How might we explain this sudden decline?

Firstly, it is perhaps the case that the measures introduced across local and central government were indeed successful in reducing levels of criminality, and that this decrease was then to some extent accurately reflected in newspaper crime reporting. The metropolitan justices and the secretaries of state by December 1744 certainly believed their efforts had resulted in an end to the crime wave, although their comments should obviously be taken with a degree of scepticism, given that it was in their best interests to reflect positively upon their work. Asked by Newcastle in April 1745 to provide an account of the justices" "actions in apprehending robberies and vagrants", the chairman of the Westminster quarter sessions Thomas Burdus duly reported that his justices had acted "with their utmost zeal and diligence", whereby "diverse of the most atrocious street robbers" were apprehended, tried, convicted, and executed. "The justices hope", Burdus went on, "that all those capital criminals are now extirpated, and that the inhabitants and all persons resorting to this City and liberty are freed from the terrors of them, which the justices ascribe to your grace's great goodness, in obtaining military aid to the civil power, by which those daring offenders were speedily subdued, and brought to justice"92. Many members of the Black Boy Alley Gang had indeed been arrested, convicted, and executed in November and December 1744 upon the evidence of an accomplice named William Harper (alias 'Old Daddy'). But this was largely due to the activities of a number of prominent metropolitan thief-takers - including members of the later infamous McDaniel gang - looking to capitalise on the raft of rewards made available in the wake of the moral panic about street robberies, rather than to the kind of magisterial zeal somewhat disingenuously painted by Burdus ${ }^{93}$.

Secondly, positive accounts in crime literature of the authorities' efforts perhaps soothed contemporary anxieties about the crime wave. Although presenting street robbery as a suddenly serious and threatening social problem in later 1744, nevertheless London newspapers, the Ordinary's Accounts, and the Proceedings, in different ways, together suggested that the criminal justice system was to at least

92 State Papers Domestic, The National Archives, SP 36/65/217.

93 See Beattie (2001, pp. 406-413). 
some extent capable of dealing with the threat, providing a measure of reassurance and counterbalance to the negative image of crime. The Proceedings and Ordinary's Accounts provided detailed reports of street robbers successfully tried, convicted, and executed, and in many ways served to further highlight the guilt of offenders and the justice of their sentences. London newspapers moreover printed countless reports of gangs broken up and offenders brought to justice through the efforts of magistrates, peace officers, and parish vestries. "It is worth observation", argued the London Evening Post at the end of October 1744, "that since the peace officers of the Cities of London and Westminster have acted in concert with each other, assisted by the foot guards, we do not hear of anything like the number of robberies committed, as before that time" $" 94$.

But there are also reasons to suggest that newspaper editors and publishers had simply lost interest in the crime wave. John Applebee evidently believed there was enough lingering reader interest in the crime wave to justify the publication of a special, two-part edition of the Ordinary's Account at the end of December. It was widely advertised in the metropolitan press, enticing consumers with the promise of "a full relation of all the robberies committed by those vile abandon'd wretches belonging to the Black Boy Alley Gang" ${ }^{95}$. Advertisements were likewise placed in a number of London newspapers relating to the publication of the December edition of the Proceedings, which avowedly contained reports of the trials of offenders "belonging to the Black Boy Alley Gang, for several street robberies; in which are many remarkable occurrences" ${ }^{\prime 96}$. Nevertheless, the December editions of theProceedings and the Ordinary's Accounts were merely the final vestiges of the printed coverage of the crime wave. The scale of crime reporting in London newspapers fell dramatically after mid-December 1744. On 13 December the Daily Advertiser expressed its belief that the subject was now exhausted and that little or nothing new could be written in relation thereto. And, remarkably, no single metropolitan newspaper provided a report of the eighteen malefactors executed at Tyburn on Christmas Eve, among who were many members of the Black Boy Alley Gang blamed for the recent spate of robberies on London's streets. The execution of so many notorious offenders would on the surface appear to be an immensely newsworthy topic, but editors chose not to cover the event, perhaps suggesting a loss of interest in the subject.

\section{CONCLUSION}

The London crime wave of 1744 closely followed the pattern evident in several other historical moral panics about violent street crime, particularly in terms of its timing, duration, and lifecycle. As with other historical moral panics, concerns about street robbery in 1744 emerged in full at the end of summer and into autumn, as winter approached and the nights began to draw in, raising anxieties about the threat posed by the dark, unlit streets of the metropolis ${ }^{97}$. Whatever the precise explanation for the

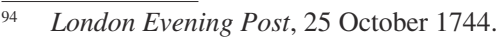

95 OBP, Ordinary's Account, December 1744 (OA17441224).

96 Daily Gazetteer, 1 January 1745.

97 King (2003).
} 
sudden decline in the printed coverage of, and panic about, the crime wave - and it is likely to have been a combination of a reduction in real levels of criminality, soothed anxieties resulting from positive reports of the authorities' efforts, and a loss of press interest - by January 1745 the moral panic about street robberies that had gripped London was over. Having begun in September, it reached a high point in November, and came to an end by the following January. The timing and duration of the moral panic about street robberies in 1744 thus closely matched that of other historical panics. And in the shift of emphasis in metropolitan crime literature throughout November and December from detailing 'the problem' of street robberies to 'what was being done about the problem', the lifecycle of crime reporting during the crime wave of later 1744 moreover mirrored other panics ${ }^{98}$.

The model of panic has proved applicable to events across various times and places. Indeed, the similarities are striking when we consider the very different contexts in which individual moral panics took place. This has drawn criticism from some that the model has become ahistorical and imprecisely applied. But as recent studies have demonstrated, by sensitively and flexibly applying it to past events, the model of moral panic can be more fully refined ${ }^{99}$. The case of 1744 certainly has some distinctive features and broadens our definition of what such panics could involve. Not only is it one of the earliest instances of a moral panic about street robbery in the eighteenth century, but it also occurred during wartime rather than peacetime, as was the norm. Moreover, the panic of 1744 was, unusually, soon followed by a more extensive and vociferous moral panic about crime in the metropolis between 1747 and 1755, fostered by a greater level of printed coverage and public discussion, and which resulted in greater changes to the criminal law and its administration ${ }^{100}$. Did the panic of 1744 have any influence on that of post-1747? It is suggestive, for example, that the call by 'Publicus' for convicted murderers to be executed soon after their trial was later adopted in practice under the terms of the 1752 Murder Act. Law and order moral panics may have had a lasting impact on the authorities beyond the immediate period of the events themselves.

Two further strands of research are therefore required. Firstly, further testing and refinement of the moral panic model is needed. Only by finding cases which do not fit the model can we hope to identify its limits. Are moral panics dependent upon a powerful press? Does the model fit for anxieties about crime and disorder in the late seventeenth and early eighteenth century when some of the key genres of crime literature surveyed here - such as the newspapers, Proceedings, and Ordinary's Accounts - were still in their infancy? Is the model applicable only to London and its environs or are comparable events evident outside the metropolis with the development of the provincial press and the growth of major provincial urban centres in the later eighteenth century? Whilst informative comparisons of moral panics across greatly varying times and places have been made, little comparison of panics within narrower time spans and geographical areas has been undertaken. Such an analysis would establish whether moral panics could have a lasting impact on the authorities or not. And secondly, more needs to be known about how the developing forces of print culture and the public sphere interacted with the administration of the

\footnotetext{
98 Ibidem.

99 Lemmings (2009a).

100 On the post-1747 crime wave see Rogers (1992); Ward (2010).
} 
law. The expanding culture of print and new opportunities for voicing public opinion in the transformative period of the eighteenth century provided central foundations for the genesis of moral panic in its modern law and order form, a phenomenon which continues to have a significant impact upon criminal justice policy today.

\author{
Richard Ward \\ Department of History \\ University of Sheffield \\ Jessop West \\ 1, Upper Hanover Street \\ UK - Sheffield S3 7RA
}

\title{
REFERENCES
}

Beattie, J., Policing and Punishment in London, 1660-1750, Oxford, Oxford University Press, 2001.

Black, J., The English Press in the Eighteenth Century, Beckenham, Croom Helm, 1987.

Cohen, S., Folk Devils and Moral Panics, London, MacGibbon and Kee, 1972.

Cowan, B., What was Masculine about the Public Sphere? Gender and the Coffeehouse Milieu in Post-Restoration England, History Workshop Journal, 2001, 51, pp. 127-157.

Davison, L., et al., The Reactive State: English Governance and Society, 1689-1750, in Davison, L., et al. (Eds), Stilling the Grumbling Hive, Stroud, Alan Sutton, 1992, pp. xi-liv.

Devereaux, S., From Sessions to Newspaper? Criminal Trial Reporting, the Nature of Crime, and the London Press, 1770-1800, London Journal, 2007, 32, pp. 1-27.

Hall, S., et al. (Eds.), Policing the Crisis: Mugging, the State, and Law and Order, London, Macmillan, 1978.

Harris, M., London Newspapers in the Age of Walpole, London, Associated University Presses, 1987.

Harris, M., Murder in Print: Representations of Crime and the Law c. 1660-1760, in Loretelli, R., De Romanis, R., (Eds), Narrating Transgression: Representations of the Criminal in Early Modern England, New York, Peter Lang, 1999, pp. 13-26.

King, P., Crime, Justice and Discretion in England, 1740-1820, Oxford, Oxford University Press, 2000.

King, P., Moral Panics and Violent Street Crime 1750-2000: A Comparative Perspective, in Godfrey, B., Emsley, C., Dunstall, G. (Eds), Comparative Histories of Crime, Cullompton, Willan, 2003, pp. 53-71.

King, P., Making Crime News: Newspapers, Violent Crime and the Selective Reporting of Old Bailey Trials in the Late Eighteenth Century, Crime, History and Societies, 2009, 13, pp. 91-116.

Lemmings, D., Conclusion: Moral Panics, Law and the Transformation of the Public Sphere in Early Modern England, in Lemmings, D., Walker, C. (Eds), Moral Panics, the Media and the Law in Early Modern England, Basingstoke, Palgrave Macmillan, 2009a, pp. 245266.

Lemmings, D., Introduction: Law and Order, Moral Panics, and Early Modern England, in Lemmings, D., and Walker, C. (Eds), Moral Panics, the Media and the Law in Early Modern England, Basingstoke, Palgrave Macmillan, 2009b, pp. 1-21.

Linebaugh, P., The London Hanged: Crime and Civil Society in the Eighteenth Century, London, Cambridge University Press, 1991. 
McGowen, R., The Problem of Punishment in Eighteenth-Century England, in Devereaux, S., and Griffiths, P. (Eds), Penal Practice and Culture, Basingstoke, Palgrave Macmillan, 2004, pp. 210-231.

McKenzie, A., Tyburn's Martyrs: Execution in England, 1675-1775, London, Hambledon Continuum, 2007.

Paley, R., Thief-Takers in London in the Age of the McDaniel Gang, c. 1745-1754, in Hay, D., Snyder, F. (Eds), Policing and Prosecution in Britain, 1750-1850, Oxford, Clarendon, 1989, pp. 301-340.

Reynolds, E., Before the Bobbies: The Night Watch and Police Reform in Metropolitan London, 1720-1830, Basingstoke, Macmillan, 1998.

Rogers, N., Confronting the Crime Wave: The Debate over Social Reform and Regulation, 1749-1753, in Davison, L., et al. (Eds), Stilling the Grumbling Hive, Stroud, Alan Sutton, 1992, pp. 77-98.

Saville, A. (Ed.), Secret Comment: The Diaries of Gertrude Savile 1721-1757, Nottingham, Kingsbridge History Society, 1997.

Shoemaker, R., Print Culture and the Creation of Public Knowledge about Crime in EighteenthCentury London, in Knepper, P., Doak, J., Shapland, J. (Eds), Urban Crime Prevention, Surveillance, and Restorative Justice, London, CRC Press, 2009, pp. 1-21.

Shoemaker, R., Print and the Female Voice: Representations of Women's Crime in London, 1690-1735, Gender and History, 2010, 22, pp. 75-91.

Shore, H., 'Undiscovered Country': Towards a History of the Criminal 'Underworld', Crimes and Misdemeanours, 2007, 1, pp. 41-68.

Snell, E., Discourses of Criminality in the Eighteenth-Century Press: The Presentation of Crime in 'The Kentish Post', 1717-1768, Continuity and Change, 2007, 22, pp. 13-47.

Ward, R., Print Culture and Responses to Crime in Mid-Eighteenth-Century London, Unpublished PhD Thesis, University of Sheffield, 2010.

Zaret, D., Origins of Democratic Culture: Printing, Petitions, and the Public Sphere in EarlyModern England, Princeton, Princeton University Press, 2000.

\section{Online Sources}

17th-18th Century Burney Collection Newspapers [http ://find.galegroup.com].

London Lives, 1690-1800 [http ://www.londonlives.org].

Old Bailey Proceedings Online [http://www.oldbaileyonline.org]. 